\title{
MINDFULNESS DAN PENERIMAAN DIRI PADA REMAJA DI ERA DIGITAL
}

\section{MINDFULNESS AND ADOLESCENTS'SELF-ACCEPTANCE IN THE DIGITAL ERA}

\author{
Natalia Christy Waney ${ }^{1}$, Wahyuni Kristinawati ${ }^{2}$, Adi Setiawan ${ }^{3}$ \\ ${ }^{123}$ Universitas Kristen Satya Wacana, Salatiga, Indonesia \\ ${ }^{1}$ christywny18@gmail.com \\ ${ }^{1} 085340000393$
}

\begin{abstract}
Abstrak
Di era digital ini, remaja melakukan eksplorasi dan mengekspresikan diri di media sosial. Media sosial menyebabkan remaja rentan terlibat dalam cyberbullying. Hal ini membuat remaja malu dengan diri sendiri dan berusaha menampilkan citra ideal di media sosial sehingga kurang mampu menerima diri apa adanya. Studi ini merupakan studi literatur yang mencoba menelusuri bagaimana mindfulness dan penerimaan diri pada remaja di era digital. Mesin pencari (search engine) digunakan sebagai alat mencari data. Ditemukan 13 literatur dan penelitian dan digunakan sebagai sumber data. Penelitian ini menyimpulkan bahwa latihan mindfulness bisa dijadikan alternatif dalam meningkatkan penerimaan diri pada remaja, dan mindfulness dapat dipraktikkan dengan memanfaatkan aplikasi smartphone. Namun, belum ditemukan penelitian yang secara khusus membuktikan efektivitas penggunaan aplikasi mindfulness dalam meningkatkan penerimaan diri pada remaja di Indonesia.
\end{abstract}

Kata Kunci: penerimaan diri, mindfulness, remaja, era digital

\begin{abstract}
In this digital era, adolescents use social media to explore and express themselves. Because of social media, adolescents become prone to cyberbullying. As result, adolescents feel shame and try the best to show the ideal image of self in social media, which makes adolescents found it difficult to accept themselves. This study is a literature study that attempts to explore mindfulness and adolescents' self-acceptance in the digital era. Search engines are used to collect the data. As a result, 13 works of literature and studies were found and used as data resources. This study concludes that mindfulness practice can be an alternative to improve selfacceptance in adolescents, and mindfulness can be practiced utilizing smartphone apps. However, there are no studies about the effectivity of mindfulness apps usage in increasing the self-acceptance of Indonesian adolescents.
\end{abstract}

Keywords: self-acceptance, mindfulness, adolescent, digital era

\section{PENDAHULUAN}

Masa remaja merupakan masa dimana individu mulai mencari tahu perasaan diri atau sense of self dan identitas pribadi, melalui eksplorasi intens mengenai nilai-nilai pribadi, kepercayaan, dan tujuan. Selama tahap ini, remaja akan memeriksa kembali identitasnya dan mencoba mencari tahu siapa dirinya yang sesungguhnya. Di masa ini, remaja mengeksplorasi berbagai kemungkinan dan mulai membentuk identitas mereka sendiri berdasarkan hasil eksplorasi mereka (McLeod, 2018). Dewasa ini, kemajuan teknologi telah membentuk cara bersosialisasi manusia, dimana jarak dan waktu bisa mempertemukan setiap individu di dunia virtual, yang termasuk didalamnya adalah media sosial. Remaja menunjukkan identitas diri yang berbeda-beda, dan remaja juga terbuka dalam mengekspresikan dirinya di media sosial (Ayun, 2015).

DOI : https://dx.doi.org/ 10.26486/psikologi.v22i2.969

URL : http://ejurnal.mercubuana-yogya.ac.id/index.php/psikologi/index

Email : insight@mercubuana-yogya.ac.id 
Seiring berjalannya waktu dan perkembangan teknologi, fitur-fitur yang diberikan media sosial pun semakin beragam dan membuat orang lebih bergantung padanya. Tristan Haris, mantan manager produksi Google, pernah mengakui bahwa platform besar seperti Facebook, Google, YouTube, Snapchat, Twitter, dan Instagram, telah menghabiskan miliaran dolar dalam penelitian psikologi untuk mengungkap cara membuat konsumen ketagihan dalam hal perhatian dan waktu yang dihabiskan dengan aplikasi-aplikasi digital tersebut (Berthon \& Pitt, 2019). Oleh karena itu, sulit untuk memisahkan diri dari platform-platform ini yang juga ternyata sangat berdampak pada psikologis remaja. Media sosial menjadi tempat terjadinya cyberbullying . Pelaku cyberbullying ingin melihat seseorang terluka, pelaku menggunakan banyak cara untuk menyerang korban dengan pesan kejam dan gambar yang mengganggu dan disebarkan untuk mempermalukan korban bagi orang lain yang melihatnya (Rifauddin, 2016). Rasa malu adalah penyesalan, bukan karena apa yang telah dilakukan atau tidak dilakukan, melainkan mengenai pengenalan akan diri sendiri bagaimana idealnya diri tersebut. Perasaan malu berhubungan erat dengan penerimaan diri. Penerimaan diri adalah proses yang memungkinkan individu memproses rasa malu tersebut (Tipping, 2011). Penerimaan diri ada ketika individu mengizinkan dirinya untuk menerima diri sebagaimana adanya, tanpa berusaha lari, mengubah, atau mencoba memperbaiki diri (Kaiser, 2017). Berdasarkan Ayun (2015), nilai individu yang ditampilkan dalam media sosial, para remaja mencoba membuat sebuah citra positif tentang diri mereka di media sosial tersebut. Remaja suka menampilkan identitas yang smart, terlihat bahagia, dan suka menampilkan hobi atau kegiatan yang disukai. Dengan kata lain, remaja menampilkan sosok ideal di media sosial, yang berarti remaja kurang mampu menerima diri apa adanya.

Lingkungan yang saat ini terintegrasi dengan teknologi tampaknya membawa banyak problema dalam kesejahteraan psikologis remaja. Savitri dan Listiyandini (2017) menyatakan bahwa mindfulness berperan positif dan signifikan terhadap setiap dimensi kesejahteraan psikologis pada remaja salah satunya terhadap dimensi penerimaan diri. Mindfulness membantu remaja untuk sadar akan dirinya sendiri dan bersedia untuk hidup dengan karakter, kelebihan dan kelemahannya dari beberapa hal yang membentuk dirinya di masa lalu (Jannah, 2019). Remaja yang lebih memiliki kesadaran utuh dan memberi perhatian penuh mengenai diri dan kehidupannya seharihari, akan mampu untuk mengatur lingkungan, memiliki kontrol terhadap aktivitas yang dijalani, menggunakan secara efektif kesempatan dalam lingkungan, mampu memilih, serta menciptakan konteks yang sesuai dengan kebutuhan dan nilai yang dimilikinya (Savitri \& Listiyandini, 2017). Kesadaran terhadap momen sekarang membuat remaja terhubung dengan orang-orang sesuai dengan keadaan mereka apa adanya. Alih-alih menumbuh suburkan rasa takut, marah, dan dendam saat menjadi korban keadaan negatif, remaja dapat move on dan melangkah maju dari situasi buruk itu dengan lebih tenang (Hidayati, 2018). Mindfulness juga terbukti memiliki kaitan dengan penerimaan diri (Jannah, 2019) dan berperan dalam peningkatan penerimaan diri remaja (Fauzia \& Listiyandini, 2018; Savitri \& Listiyandini, 2017). Dengan demikian, praktik mindfulness akan 
sangat berguna dalam penerimaan diri pada remaja yang saat ini menghadapi isu-isu sosial akibat paparan terhadap media sosial.

\section{METODE}

Tulisan ini merupakan studi literatur. Peneliti menggunakan mesin pencari (search engine) untuk menelusuri literatur-literatur dan penelitian-penelitian yang relevan dengan fokus kajian, yaitu mindfulness dan penerimaan diri pada remaja di era digital. Dari beberapa literatur dan penelitian yang diperoleh, hanya 13 sumber yang memberikan informasi secara spesifik, yang kemudian digunakan sebagai sumber data dalam studi ini, yaitu (pemaparan jurnal diurut berdasarkan tahun terbit):

1. Yang pertama adalah buku dari Bernard, M. E. tahun 2013, yang berjudul The Strength of SelfAcceptance.

2. Yang kedua adalah buku dari Kashdan, T. B., \& Ciarrochi, J. tahun 2013, yang berjudul Mindfulness, acceptance, and positive psychology: The seven foundations of well-being.

3. Yang ketiga adalah buku dari Marotta, J. tahun 2013, yang berjudul 50 mindful steps to selfesteem : everyday practices for cultivating self-acceptance and self-compassion.

4. Yang keempat adalah buku dari Langer, E. J. tahun 2016, yang berjudul The power of mindful learning.

5. Yang kelima adalah penelitian Savitri, W. C., \& Listiyandini, R. A. tahun 2017, yang berjudul Mindfulness dan Kesejahteraan Psikologis pada Remaja, yang diterbitkan dalam Psikohumaniora: Jurnal Penelitian Psikologi.

6. Yang keenam adalah penelitian Xiao, Q., Yue, C., He, W., \& Yu, J. Y. tahun 2017, yang berjudul The mindful self: A mindfulness-enlightened self-view, yang diterbitkan dalam Frontiers in Psychology.

7. Yang ketujuh adalah penelitian Fauzia, Retty; Listiyandini, R. A. tahun 2018, yang berjudul Peran Trait Mindfulness (Rasa Kesadaran) Terhadap Penerimaan Diri Pada Remaja Dengan Orangtua Bercerai, yang diterbitkan dalam Seminar Nasional dan Temu Ilmiah Positive Psikologi.

8. Yang kedelapan adalah penelitian Hidayati, N. tahun 2018, yang berjudul Mindfulness Based Stress Reduction (MBSR) untuk Resiliensi Remaja yang Mengalami Bullying, yang diterbitkan dalam National Conference Psikologi UMG.

9. Yang kesembilan adalah buku dari Neff, K., \& Germer, C. tahun 2018, yang berjudul The Mindful Self-Compassion Workbook: A Proven Way to Accept Yourself, Build Inner Strength, and Thrive.

10. Yang kesepuluh adalah penelitian Ningsih, H. E. W., Dwidiyanti, M., \& Hartati, E. tahun 2018, yang berjudul Mindfulness Mobile Application Menurunkan Tingkat Stres Mahasiswa: A Literature Review, yang diterbitkan dalam Holistic Nursing and Health Science. 
11. Yang kesebelas adalah penelitian Huberty, J., Green, J., Glissmann, C., Larkey, L., Puzia, M., \& Lee, C. tahun 2019, yang berjudul Efficacy of the mindfulness meditation mobile app "calm" to reduce stress among college students: Randomized controlled trial, yang diterbitkan dalam Journal of Medical Internet Research.

12. Yang keduabelas adalah penelitian Jannah, A. M. tahun 2019, yang berjudul Hubungan Mindfulness dan Penerimaan Diri pada Remaja dengan Orang Tua Tunggal, yang merupakan skripsi dari Universitas Muhammadiyah Malang.

13. Yang ketigabelas adalah buku dari Stahl, Bob \& Goldstein, E. tahun 2010, yang berjudul $A$ Mindfulness-Based Stress Reduction Workbook (A New Harbinger Self-Help Workbook).

\section{HASIL DAN PEMBAHASAN}

\section{Penerimaan Diri}

Germer (2009) mendefinisikan penerimaan diri sebagai kemampuan individu untuk dapat memiliki suatu pandangan positif mengenai siapa dirinya yang sebenar-benarnya, dan hal ini tidak dapat muncul dengan sendirinya, melainkan harus dikembangkan oleh individu. Penerimaan diri ada ketika individu mengizinkan dirinya untuk menerima diri sebagaimana adanya, tanpa berusaha lari, mengubah, atau mencoba memperbaiki diri (Kaiser, 2017). Penerimaan diri bersifat transformatif. Individu yang berfokus pada apa yang salah, berusaha untuk mengisi kekosongan dalam upaya putus asanya untuk menjadi baik-baik saja. Tetapi ketika berfokus pada apa yang benar, individu tersebut mulai dari perspektif bahwa dirinya menerima diri apa adanya, dengan semua kekurangan dan ketidaksempurnaan (Marotta, 2013).

Berdasarkan Bernard (2013) penerimaan diri dapat dibagi menjadi dua aspek, yaitu: (1) Kesadaran diri dan penghargaan akan karakteristik positif dan pengembangan potensi (kepribadian, bakat, keluarga, agama, karakteristik budaya) dan (2) Rasa bangga dan menerima diri sendiri tanpa syarat ketika peristiwa negatif terjadi (kegagalan, kritik atau penolakan dari orang lain) atau ketika terlibat dalam perilaku interpersonal yang negatif; tidak menilai diri secara negatif. Menurut Marotta (2013), untuk mencapai penerimaan, individu perlu untuk memperkuat kesadaran atau keadaan mindful, dengan belajar untuk memperhatikan moment saat ini dan menjadi diri yang sesungguhnya, daripada mencoba menganalisis dan menjelaskan bagaimana caranya untuk pergi dari satu keadaan ke keadaan lain. Oleh karena itu, mindfulness dapat menciptakan perubahan positif pada penerimaan diri individu (Xiao, dkk., 2017).

Selain itu, penerimaan diri dapat ditingkatkan dengan pelatihan berpikir positif. Individu yang berpikir positif cenderung memusatkan perhatian pada hal-hal positif dari berbagai permasalahan yang sedang dihadapinya, sehingga individu mulai mendapatkan insight mengenai aktivitas positif yang dapat dijadikan sebagai pengalih agar tidak berfokus pada hal-hal yang bersifat negatif (Bilicha, dkk., 2020). Cognitive Behavioral Therapy (CBT) juga terbukti efektif dalam meningkatkan penerimaan diri (Pramono \& Astuti, 2017). Namun, baik CBT maupun 
pelatihan berpikir positif, keduanya hanya dapat dipraktikkan oleh ahli pada kedua bidang tersebut, sedangkan untuk mindfulness, remaja dapat mempraktikkannya sendiri pada kesehariannya (Neff \& Germer, 2018).

\section{Mindfulness}

Mindfulness pada dasarnya berarti memperhatikan dengan keterbukaan, keingintahuan, dan fleksibilitas. Dalam keadaan sadar, pikiran dan perasaan yang rumit memiliki dampak dan pengaruh yang jauh lebih kecil terhadap perilaku (Kashdan \& Ciarrochi, 2013). Mindfulness melibatkan kesadaran akan pengalaman dari waktu ke waktu secara jelas dan seimbang. Artinya, terbuka terhadap realitas saat ini, membiarkan semua pikiran, emosi, dan sensasi memasuki kesadaran tanpa perlawanan atau penghindaran (Neff \& Germer, 2018). Dengan demikian, bagian dari mindfulness adalah "bersama dengan" diri apa adanya, terlepas dari keinginan untuk menjadi sebaliknya (Marotta, 2013). Kebalikan dari mindfulness adalah mindlessness. Mindlessness terjadi ketika atensi tidak terarah sama sekali, melainkan mengembara tanpa arah, dan membawa individu turut larut dalam lamunan. Dalam kondisi mindless, kesadaran sangat menurun, di mana individu tersebut hanya bereaksi secara otomatis, tanpa benar-benar memperhatikan apa pun yang sedang terjadi. Mindlessness erat kaitannya dengan fenomena autopilot, yaitu ketika individu menghadapi berbagai masalah dalam kehidupan dengan otomatis, dengan respons-respons yang biasa dilakukan, tanpa menyadarinya, tanpa menghayatinya (Arif, 2016; Langer 2016; Lopez, 2009). Mindfulness membawa individu keluar dari pola perilaku otomatis tersebut; daripada bereaksi tanpa berpikir, individu secara sadar merespons dengan cara yang lebih produktif. Mindfulness lebih menggunakan kesadaran lebih dari menggunakan pemikiran sebagai jalan keluar dari situasi yang menantang (Marotta, 2013).

Mindfulness melawan kecenderungan menghindari pikiran dan emosi yang menyakitkan, memungkinkan individu untuk menghadapi kebenaran dari pengalaman, bahkan ketika pengalaman tersebut tidak menyenangkan. Pada saat yang sama, mindfulness mencegah individu menyerap dan mengenali pikiran atau perasaan negatif secara berlebihan, agar tidak terperangkap dan terhanyut oleh reaksi aversif (Neff \& Germer, 2018). Menurut Langer (2016), ada empat aspek mindfulness, yaitu: (1) Memandang suatu situasi dari beberapa perspektif, (2) melihat informasi yang disajikan dalam situasi tersebut sebagai hal baru, (3) memperhatikan konteks di mana individu menerima informasi, dan (4) membuat kategori baru dimana informasi ini dapat dipahami. Selanjutnya, dalam keadaan mindful, individu mengarahkan hidupnya dengan intensi, dengan demikian individu dapat memusatkan perhatian pada pribadinya yang sesungguhnya dan kehidupannya, sehingga tidak kehilangan dirinya dalam hal-hal yang tidak penting (Marotta, 2013).

Stahl dan Goldstein (2010) membagi praktik mindfulness dalam dua kategori, yaitu praktik formal dan informal. Praktik formal sama seperti melakukan meditasi dengan posisi duduk. Meditasi mindfulness formal ini dapat dipraktikkan dengan cara: 
1. Mindfulness of breathing (kesadaran terhadap pernapasan). Individu menyadari kualitas pernapasan saat nafas masuk dan nafas keluar. Kesadaran ini akan memberikan pemahaman mengenai bagaimana segala sesuatu berubah dalam hidup.

2. Mindfulness of sensation (kesadaran terhadap sensasi). Setelah menghabiskan beberapa waktu dengan latihan pernapasan, individu akan memperluas kesadaran pada sensasi fisik, dengan cara mempertahankan perhatian pada pengalaman indrawi, yaitu dengan menyadari setiap sensasi yang muncul dan surut.

3. Mindfulness of hearing (kesadaran terhadap apa yang didengar). Fokus kesadaran pada pendengaran dapat dilakukan dengan mendengarkan berbagai suara yang muncul dan hilang. Apapun yang terdengar, cobalah untuk tidak menilai suara itu baik atau buruk.

4. Mindfulness of thoughts and emotions (kesadaran terhadap pikiran dan emosi). Setelah berfokus pada suara, individu akan mengubah objek meditasinya pada peristiwa mental, yaitu pikiran dan emosi. Mindfulness melibatkan kemampuan seseorang untuk mengobservasi dan merasakan pemikiran dan perasaan saat ia muncul, berkembang dan menghilang. Individu tidak perlu menganalisa atau mencari tahu hal tersebut, melainkan dengan sederhana melihatnya sebagai bentuk mental yang muncul dan menghilang.

5. Choiceless awareness (kesadaran yang tidak dipilih). Aspek yang terakhir dan yang paling luas dalam meditasi mindfulness adalah choiceless awareness, atau kesadaran pada situasi saat ini. Dalam latihan ini, moment saat ini menjadi objek utama atensi. Choiceless awareness mengarahkan individu untuk menjadi sadar sepenuhnya terhadap apapun yang muncul pada saat ini yang tidak ada akhirnya. Individu memperhatikan apapun yang timbul dari tubuh, pikiran, seperti sensasi, suara atau fenomena sensori lainnya, atau kejadian mental seperti pola pikir dan emosi.

Praktik mindfulness secara informal dapat dilakukan dengan cara sadar terhadap kebiasaan dan perilaku sehari-hari. Berdasarkan Neff dan Germer (2018), mindfulness dapat dipraktikkan setiap saat sepanjang hari dengan cara sebagai berikut:

1. Pilih aktivitas biasa, seperti minum kopi di pagi hari, mandi, atau mengenakan pakaian. Pilih aktivitas yang dilakukan saat mengawali hari sebelum perhatian terbagi-bagi ke berbagai arah.

2. Pilih satu pengalaman sensorik untuk dijelajahi, seperti sensasi saat minum kopi atau sensasi ketika air menyentuh tubuh saat mandi.

3. Benamkan diri dalam pengalaman tersebut, nikmati semaksimal mungkin. Kembalikan pikiran pada sensasi lagi dan lagi ketika menyadari bahwa pikiran tersebut telah menghilang.

4. Bawa kesadaran tersebut sampai aktivitas selesai.

Mindfulness memberikan ruang bagi mental, dengan demikian individu memiliki kebabasan untuk memilih cara merespon terhadap situasi tertentu (Neff \& Germer, 2018). 


\section{Peran Mindfulness dalam Penerimaan Diri pada Remaja di Era Digital}

Semakin canggih teknologi, semakin mudah pula bagi remaja untuk melakukan meditasi mindfulness. Di era digital ini, mindfulness dapat dipraktikkan cukup dengan menggunakan aplikasi smartphone, yang didalamnya lengkap dengan meditasi mindfulness yang terpadu oleh praktisipraktisi mindfulness. Aplikasi yang praktis dan mudah digunakan, serta fleksibilitas waktu, tempat, maupun fitur audio yang sangat jelas mampu membawa remaja yang sedang berada di tengah kota yang bising ke dalam suasana tengah hutan atau pinggir danau dengan kicauan burung yang menenangkan. Dampak globalisasi pun dapat dirasakan disini, yaitu ketika tren pelatihan mindfulness di Amerika membawa pengaruh bagi Indonesia. Di Amerika, aplikasi mindfulness mulai merebak pada tahun 2007 dan hingga saat ini telah menciptakan 1000 aplikasi meditasi (Berthon \& Pitt, 2019). Berdasarkan Ningsih, dkk., (2018) ada beberapa aplikasi mindfulness yang dapat digunakan untuk menurunkan tingkat stres, yaitu headspace, mindfulness app, Naturespace, Universal breathing Pranayama, Breathe2Relax, Stress relief self-hypnosis for iPad dan DeStressify. Calm juga merupakan salah satu aplikasi meditasi mindfulness lainnya yang terbukti efektif untuk mengurangi stres dan meningkatkan mindfulness dan self-compassion (Huberty, dkk., 2019). Seperti yang dilansir dari suarasurabaya.net, Indonesia juga sudah memiliki aplikasi meditasi bernama Riliv Hening yang diluncurkan sejak Kamis (10/10/2019). Aplikasi-aplikasi ini pun bisa menjadi alternatif bagi remaja di era digital ini dalam meningkatkan kesadaran yang juga baik untuk penerimaan dirinya, sehingga bisa dimanfaatkan remaja Indonesia dalam melakukan latihan mindfulness. Namun, masih belum terdapat penelitian yang menunjukkan efektivitas penggunaan aplikasi-aplikasi tersebut secara khusus terhadap penerimaan diri remaja. Disamping itu, perbedaan jumlah aplikasi di Amerika dan di Indonesia serta jangka waktu perkembangannya juga menunjukkan bahwa mindfulness di Indonesia masih kurang mendapat perhatian.

\section{KESIMPULAN}

Beberapa hal yang dapat disimpulkan dari uraian di atas, yaitu:

1. Langkah awal menuju penerimaan diri yang positif adalah dengan memiliki kesadaran dengan berfokus pada moment saat ini, dan menerima setiap sensasi, pikiran, dan emosi dari pengalaman tanpa memberi penilaian melalui latihan mindfulness.

2. Selain mindfulness, pelatihan berpikir positif dan Cognitive Behavioral Therapy juga efektif dalam meningkatkan penerimaan diri remaja. Namun keduanya hanya dapat dipraktikkan oleh ahli pada kedua bidang tersebut, sedangkan untuk mindfulness, remaja dapat mempraktikkannya sendiri pada kesehariannya.

3. Praktik mindfulness terbagi atas dua kategori, yaitu praktik formal yang berupa meditasi, dan praktik informal yang bisa diintegrasikan dengan aktivitas sehari-hari. Di era digital ini, mindfulness dapat dipraktikkan cukup dengan menggunakan aplikasi smartphone, yang 
didalamnya lengkap dengan meditasi mindfulness yang terpadu oleh praktisi-praktisi mindfulness.

4. Aplikasi-aplikasi mindfulness seperti headspace, mindfulness app, Naturespace, Universal breathing Pranayama, Breathe2Relax, Stress relief self-hypnosis for iPad dan DeStressify, dapat digunakan untuk menurunkan tingkat stres. Penelitian lain juga menemukan bahwa aplikasi Calm juga merupakan salah satu aplikasi meditasi mindfulness lainnya yang terbukti efektif untuk mengurangi stress dan meningkatkan mindfulness dan self-compassion. Namun belum ditemukan penelitian yang secara khusus membuktikan efektivitas penggunaan aplikasi mindfulness dalam meningkatkan penerimaan diri. Maka dari itu, aplikasi-aplikasi ini hanya bisa dijadikan alternatif untuk melakukan praktik mindfulness.

\section{DAFTAR PUSTAKA}

Arif, I. S. (2016). Psikologi positif: Pendekatan saintifik menuju kebahagiaan. Gramedia Pustaka Utama.

Ayun, P. Q. (2015). Fenomena remaja menggunakan media sosial dalam membentuk identitas. CHANNEL Jurnal Komunikasi, 3(2), 1-16. https://doi.org/10.12928/channel.v3i2.3270

Baskoro, A. H. (2019). Riliv launching aplikasi meditasi online pertama di Indonesia. https://www.suarasurabaya.net/kelanakota/2019/Riliv-Launching-Aplikasi-MeditasiOnline-Pertama-di-Indonesia/

Berthon, P. R., \& Pitt, L. F. (2019). Types of mindfulness in an age of digital distraction. In Business Horizons. https://doi.org/10.1016/j.bushor.2018.10.003

Bernard, M. E. (2013). The strength of self-acceptance. In the strength of self-acceptance: Theory, practice and research. Springer Science + Business Media. https://doi.org/10.1007/978-14614-6806-6

Bilicha, P.N., Nashori, F., \& Sulistyarini, I. (2020). Pelatihan Berpikir positif untuk meningkatkan penerimaan diri pada anak yang sedang menjalani masa pembinaan di lembaga pembinaan khusus anak klas I Kutoarjo. Skripsi. Universitas Islam Indonesia.

Fauzia, R., \& Listiyandini, R. A. (2018). Peran trait mindfulness (rasa kesadaran) terhadap penerimaan diri pada remaja dengan orangtua bercerai. Seminar Nasional dan Temu Ilmiah Positive Psikologi, 152-163.

Germer, C. (2009). The mindful path to self-compassion. New York: In Guilford.

Hidayati, N. (2018). Mindfulness based stress reduction (MBSR) untuk resiliensi remaja yang mengalami bullying. Proceeding National Conference Psikologi UMG 2018, p. 40-49, July 2019

Huberty, J., Green, J., Glissmann, C., Larkey, L., Puzia, M., \& Lee, C. (2019). Efficacy of the mindfulness meditation mobile app "calm" to reduce stress among college students: Randomized controlled trial. Journal of Medical Internet Research, 7(6), https://doi.org/10.2196/14273

Kaiser, S. (2017). The self-love experiment. Penguin. 
Kashdan, T. B., \& Ciarrochi, J. (Eds.). (2013). The context press mindfulness and acceptance practica series. Mindfulness, acceptance, and positive psychology: The seven foundations of well-being. Context Press/New Harbinger Publications.

Jannah, A. M. (2019). Hubungan mindfulness dan penerimaan diri pada remaja dengan orang tua tunggal. Skripsi. Malang: Fakultas Psikologi, Universitas Muhammadiyah Malang.

Langer, E. J. (2016). The power of mindful learning. Da Capo Press.

Lopez, S. J. (2009). The encyclopedia of positive psychology. In Blackwell Publishing. Blackwell Publishing.

Marotta, J. (2013). 50 mindful steps to self-esteem: Everyday practices for cultivating selfacceptance and self-compassion. New Harbinger Publications.

McLeod, S. A. (2008). Erik Erikson / Psychosocial Stages - Simply Psychology. Retrieved from http://www.simplypsychology.org

Neff, K., \& Germer, C. (2018). The Mindful self-compassion workbook: A Proven way to accept yourself, build inner strength, and thrive (paperback). In Guilford Publications.

Ningsih, H. E. W., Dwidiyanti, M., \& Hartati, E. (2018). Mindfulness mobile application menurunkan tingkat stres mahasiswa: A literature review. Holistic Nursing and Health Science, 1(20, 116-125. https://doi.org/10.14710/hnhs.1.2.2018.116-125

Pramono, R. B., \& Astuti, D. (2017). Cognitive behavioral therapy as an effort to improve self acceptance of adolescents in orphanage. The Open Psychology Journal. 10, 161-169. https://doi.org/10.2174/1874350101710010161

Rifauddin, M. (2016). Fenomena cyberbullying pada remaja (studi analisis media sosial Facebook). Khizanah Al-Hikmah : Jurnal Ilmu Perpustakaan, Informasi, Dan Kearsipan, 4(10), 35-44.

Savitri, W. C., \& Listiyandini, R. A. (2017). Mindfulness dan kesejahteraan psikologis pada remaja. Psikohumaniora: Jurnal Penelitian Psikologi, 2(1), 43-59. https://doi.org/10.21580/pjpp.v2i1.1323

Stahl, B., \& Goldstein, E. (2010). A mindfulness-based stress reduction workbook (a new harbinger self-help workbook). New Harbinger Publications.

Tipping, C. (2011). Radical self-forgiveness: The Direct path to true self-acceptance. Sounds True, Inc.

Xiao, Q., Yue, C., He, W., \& Yu, J. Y. (2017). The mindful self: A mindfulness-enlightened selfview. Frontiers in Psychology, 8, 1-10. https://doi.org/10.3389/fpsyg.2017.01752 